\title{
TOMORROW WITH GEOSYNTHETICS: A COST EFFECTIVE BUILDING CONSTRUCTION MATERIAL
}

\author{
Aanand Jain ${ }^{1}$ \\ ${ }^{l}$ CEO, M/s Green Infrastructures Systems Pvt. Ltd. (GISPL), Maharashtra, India
}

\begin{abstract}
Generally Soil demonstrates high compressive strength similar to concrete, but fundamentally no tensile strength, when load applied on it. To provide tensile strength in soils, it needs reinforcement like steel i.e. required for concrete. The diverse ranges of polymeric Geosynthetics materials typically are being used to reinforce soils. Geosynthetics are relatively light and flexible; possess a high tensile strength, even extensible during application of loads. When soil and Geosynthetics reinforcement are combined, coherent reinforced soil mass developed, possessing both high compressive and tensile strength (similar, in principle, to reinforced concrete). Geosynthetics is a generic term used to encompass family of various flexible polymer materials used in geotechnical engineering. Geosynthetics family is quite large and comprises wide variety of products like Geogrids, Geonets, Geomembranes, geotextiles, Geosynthetics Clay liners, Geocomposites, Geocells, Geotube, Geobags, Geofoam, Glass Grids, Paving fabric, Geostrips, Jute geotextiles etc. but this paper focus on products Geogrids, Geotextiles, Geocells and Jute geotextiles as an alternative of conventional building materials with cost effectiveness, great value in enhancing the performance of traditional materials simultaneously reduce maintenance cost and savings of carbon footprints.
\end{abstract}

Over the last three decades Geosynthetics are being increasingly used in civil engineering applications like road construction, high embankments, retaining structures and erosion control etc. In addition to the application of Geosynthetics in road construction, they can be used for number of others applications like, steep slope stabilization, filter and/or drainage control in embankment and dam, lands reclamation, landfills, canal lining, strengthening of weak foundation soil for railway embankment, reducing the ballast thickness for railway etc. Geosynthetics products can be used effectively in building construction related activities as alternative of conventional material/techniques. The some of the examples by inclusion of Geosynthetics in soil mass are: Improvement of bearing capacity for building foundation where foundation soil needs improvement, Construction of internal roads with lower maintenance cost within any township by controlling rutting/cracking/pot holes in the road, Construction cost effective internal roads by reducing the thickness of natural base materials needed, Strengthening of weak subgrade for development of internal roads, Construction of Reinforced soil walls (RSW) for development of outdoor sports complex with sitting arrangements. Erosion protection using Jute and coir geotextiles/geogrid, Landscaping of sloping area using Geo cells, development of children play area are also, the examples of uses of Polymer/Natural Geosynthetics as alternative of conventional building construction material.

Keywords: Geosynthetics, Geogrids, Geotextile, Geocomposite, Geocell, Building Construction material, Road Construction, Sports Complex, Filtration, Drainage, Reinforcement $* * *$

\section{BACKGROUND}

The growing scarcity of affordable land and easy to build upon is causing engineers, contractors and developers (Government/Private) to find innovative techniques to use less desirable parcels of land. Areas with rough terrain and/or steep slopes were once considered as being unfeasible for development. Much of these areas now can be made virtually flat, and make them usable, through the employment of cost effective reinforced retaining walls and steepened slopes, using required cost effective Geosynthetics. Construction of rutting free, low maintenance roads is also challenging business to government/contractors/engineers. In last three decades, it is demonstrated by using Geosynthetics in different applications of civil engineering (especially highway engineering) that Geosynthetics are well developed, understood products and have great value in enhancing the performance of traditional materials simultaneously reduce maintenance cost of structures. In last thirty years, Geosynthetics materials have added entirely a new dimension to the Civil Engineering across the world, but its exposure in the field building construction is in negligible or in the stage of nuisance, especially in India. The applications of Geosynthetics products presented in this paper demonstrate its use as an alternative of building construction materials.

\subsection{Types of Geosynthetics}

As per ASTM definition, Geosynthetics is a planar product manufactured from a polymeric material used with soil, rock or other geotechnical-related material as an integral part of a civil engineering project, structure, or system. Geosynthetics are generally identified by polymer, type of fiber or yarn, ultimate and long term design tensile strength (using 
reduction factors), mass per unit area or thickness. The relatively very less thickness of Geosynthetics as compared to their natural soil equivalents is a strategic advantage insofar as light weight on the subgrade, less airspace used. Its multi-functional technical properties like tensile strength, capacity of filtration/drainage etc. make Geosynthetics very good alternative of sand, gravels and other soil materials, therefore in turn avoidance of quarried is possible. The ease installation of Geosynthetics products have one more significant advantage in comparison to thick soil layers (sands, gravels, or clays) demanding large earthmoving equipment. Design solutions using Geosynthetics products, compare to design solutions using their natural counterparts have cost and invariably sustainability (lower $\mathrm{CO}_{2}$ footprints) advantages.

Family of Geosynthetics comprises eight main products i.e. Geotextiles, Geogrids, Geomembranes, Geocomposites, Geocells, Geofoam, Geosynthetics clay liners, Geonets. Five major functions of Geosynthetics products are: reinforcement, separation, filtration, drainage and as a fluid/moisture barrier. However this paper will focus on reinforcement, separation, moisture barrier and drainage functions to describe advantage of Geosynthetics like Geogrids, Geotextiles, Geocomposites, Geomembranes and Geocells as an alternative material in building construction.

\section{GEOGRIDS, GEOTEXTILES AND} GEOCOMPOSITES

\subsection{Geogrid}

Geogrids are manufactured by polymers like PET (Resins as per ASTM D2455, ASTM 4603; Carboxyl end group<30, Molecular weight $>25000$, ) or HDPE (Resins as per ASTM D1248), Flexible or Stiff respectively formed into a very open network like configuration i.e., they have apertures (varies $20 \mathrm{~mm}$ to $200 \mathrm{~mm}$ ) between individual ribs in the transverse and longitudinal directions. PET and HDPE Geogrids have minimum UV resistance as per ASTM D4355. Geogrids are (a) either stretched in one, two or three directions for improved physical properties, (b) made on woven/knitted machinery by standard textile manufacturing methods, or (c) by laser or ultrasonically bonding rods or straps together.

They facilitate excellent interlocking with soil so there main exclusive application of is soil reinforcement. Geogrids that are having tensile strength in one direction, Machine direction (MD) are called Uniaxial Geogrids as shown in Fig. 1 and 2, used as reinforcement layers in retaining walls, embankments with steep slope and basal reinforcement for embankment resting on weak subsoil/foundation soil.

Geogrids that are having tensile strength in two directions , Machine (MD) as well as Cross Machine directions (CD) are referred Biaxial geogrids as shown in Fig. 3 and 4, used in roads bases, below rail tracks, ground reinforcement etc. where the direction of principle stress is uncertain.

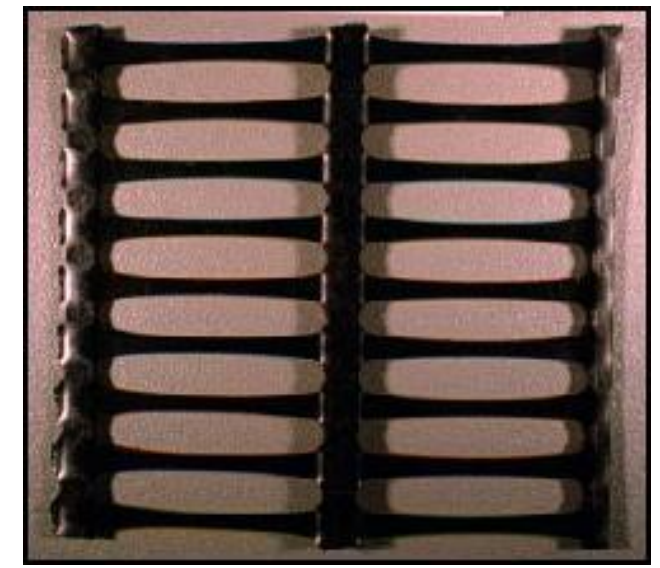

Fig -1: Uniaxial HDPE Geogrid

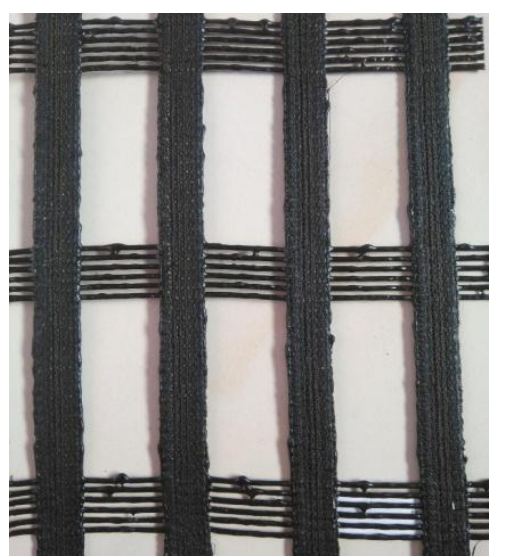

Fig -2: Uniaxial Polyester (PET Geogrid)

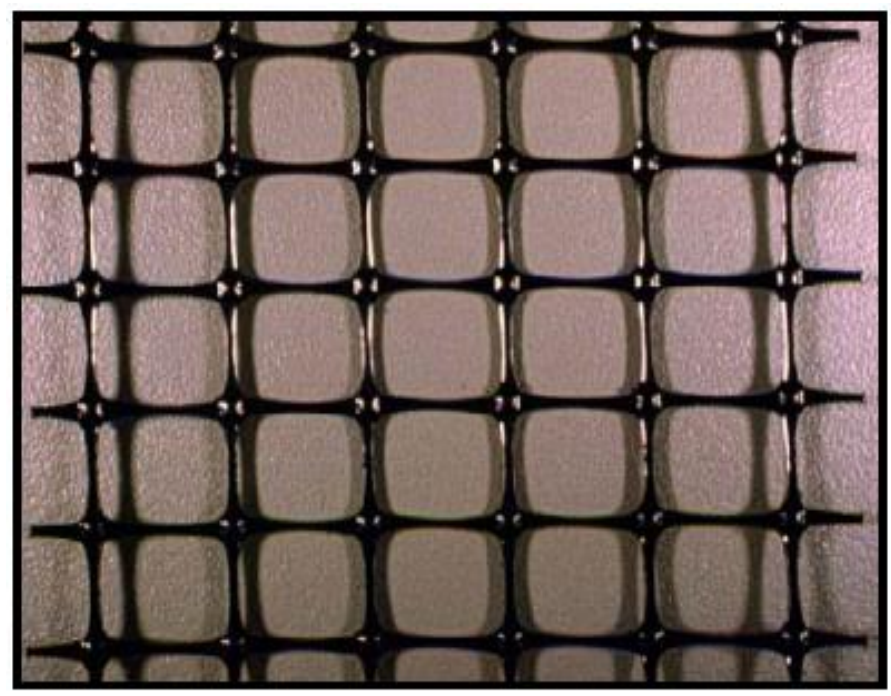

Fig -3: Biaxial HDPE Geogrid 


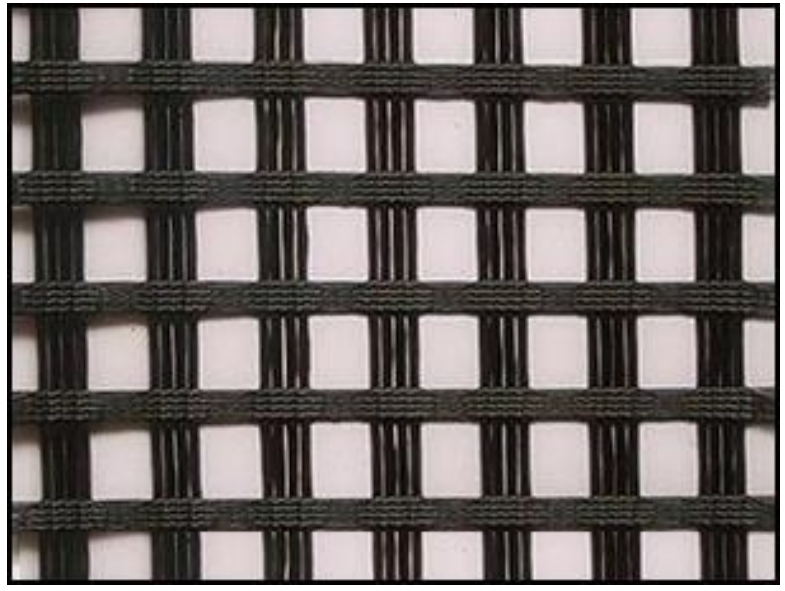

Fig -4: Biaxial PET Geogrid

\subsection{Geotextile}

Geotextile are sheet like flexible permeable products mainly divided in three categories i.e. Woven and Non-Woven and Knitted. Geotextiles are usually manufactured from a polymer like polypropylene (PP), polyester (PET, Fig. 5), polyethylene (PE) and polyamides. The polymers used in the form of staple fibers, monofilament, multifilament, raffia tapes or fibrillated raffia tapes. They are used to increase soil stability, provide erosion control, separation, filtration and drainage.

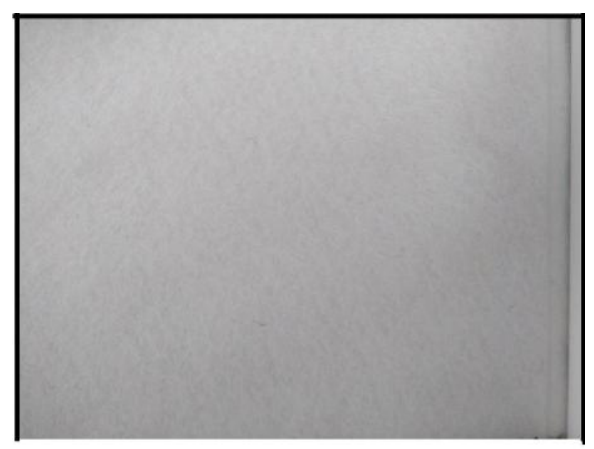

Fig. -5: Type of Geotextile

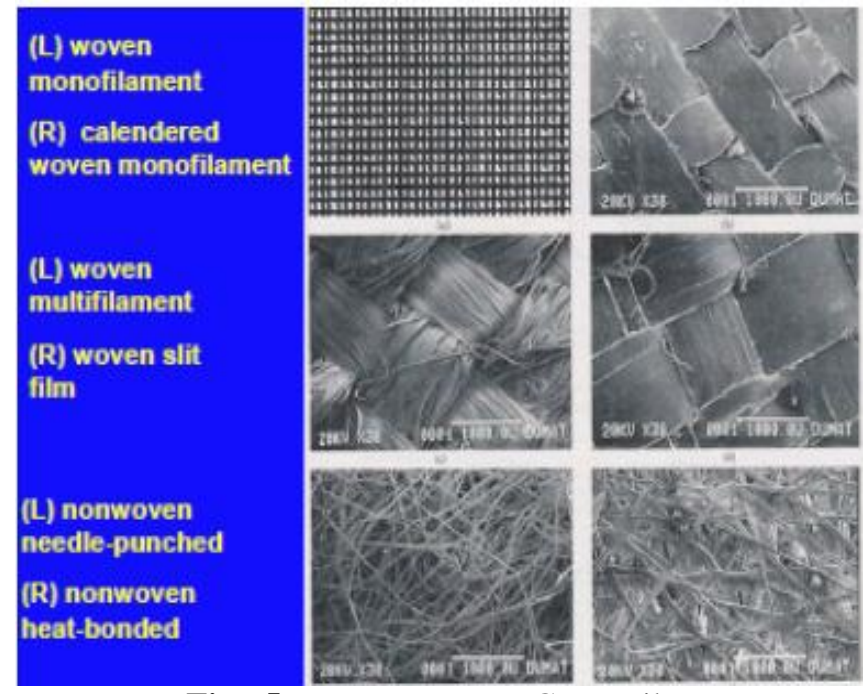

Fig. -5: PET Nonwoven Geotextile
However natural fibers [5] like jute and coir are also being used for manufacturing of Geotextile. These geotextiles mainly used for protection of slope, river bank from erosion by developing grass vegetation. Weft direction yarns of Geotextile function as a speed breaker across surface runoff so velocity of flow reduces. Natural fibers have approximately $500 \%$ water holding capacity on dry weight so they help in grass vegetation.

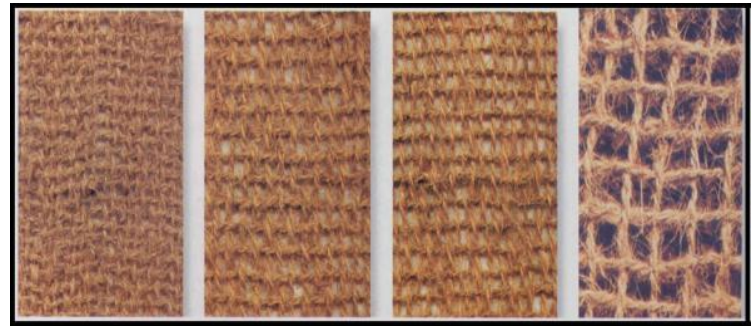

Fig -7: Jute Geotextile

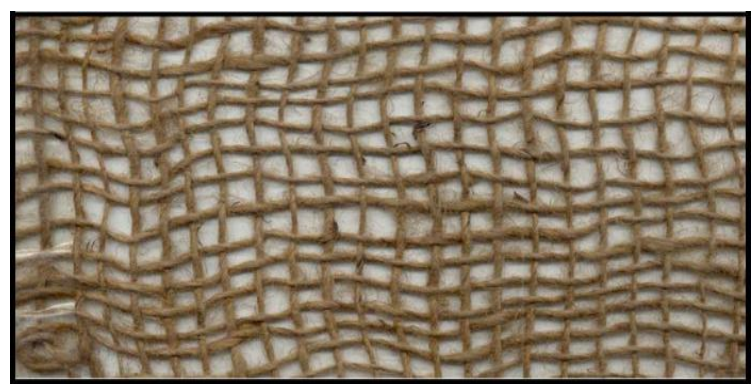

Fig -8: Coir Geotextile

\subsection{Geocomposite}

Geocomposite is a combination of minimum two different functioning Geosynthetics products among geotextiles, geogrids, geonets and/or geomembranes. Any one of these four Geosynthetics or all four Geosynthetics can be combined with another synthetic material also (e.g. deformed plastic sheets or steel cables) or even with soil. As example, a geonet or geospacer with geotextile/bentonite/ geotextile sandwich are both geocomposites. The major functions comprise separation, reinforcement, filtration, drainage and containment. A much thicker drainage layer can be replaced with a thin layer of Geocomposite.

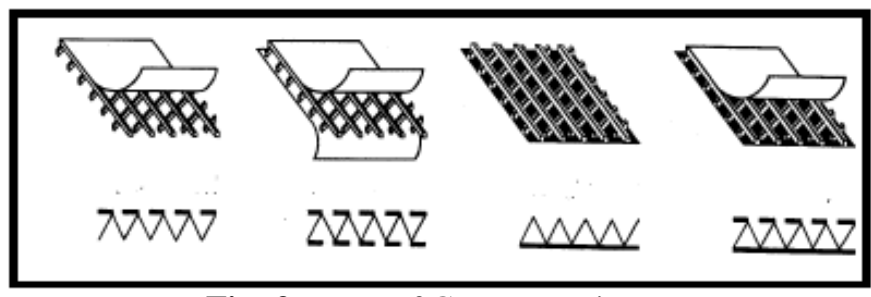

Fig -9: Type of Geocomposites

\subsection{Applications of Geosynthetics}

\subsubsection{Wrapped around Reinforced Soil Walls}

M/s Green Infrastructures Systems Pvt. Ltd. used polyester uniaxial geogrid to design wrapped around reinforced soil retaining walls for development of outdoor sports activities complex within a housing complex at Mhow, Madhya 
Pradesh in year 2014. The concept of wrapped around walls were proposed to builder (Akshay Infra.) in place of conventional costly R.C.C. retaining walls. The concrete road for movement of vehicles rest on the top of wrapped around retaining walls. The maximum height of walls is $8.40 \mathrm{~m}$. The designs and construction of walls were based on guidelines of FHWA-NHI-00-43 recommended by U.S. Department of Transportation Federal Highway Administration. Builder/developer purchased polyester geogrid and nonwoven geotextile while reinforced fill material abundantly available at site free of cost.

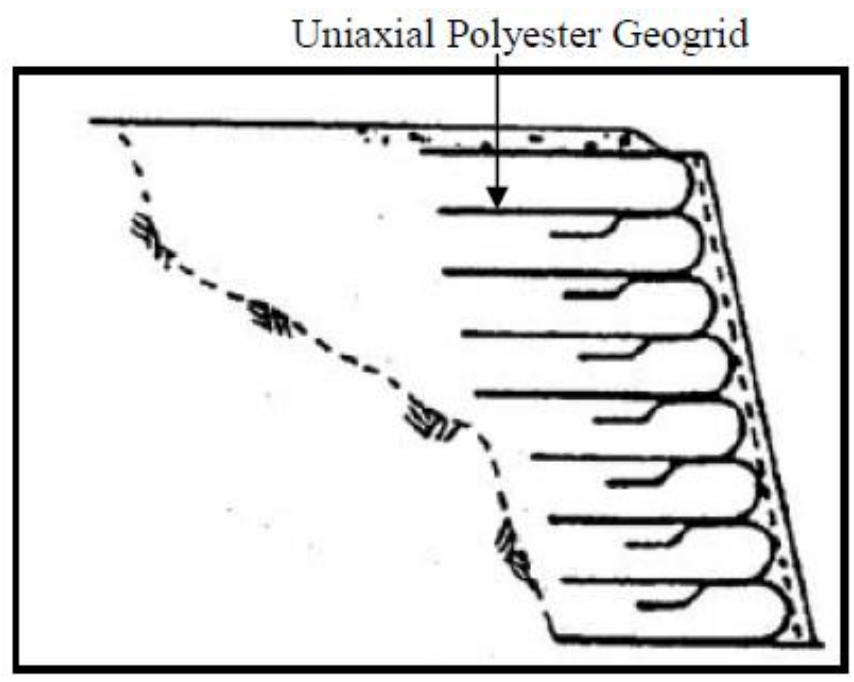

Fig -10: Typical Section of Wrapped Around Reinforced Soil Walls

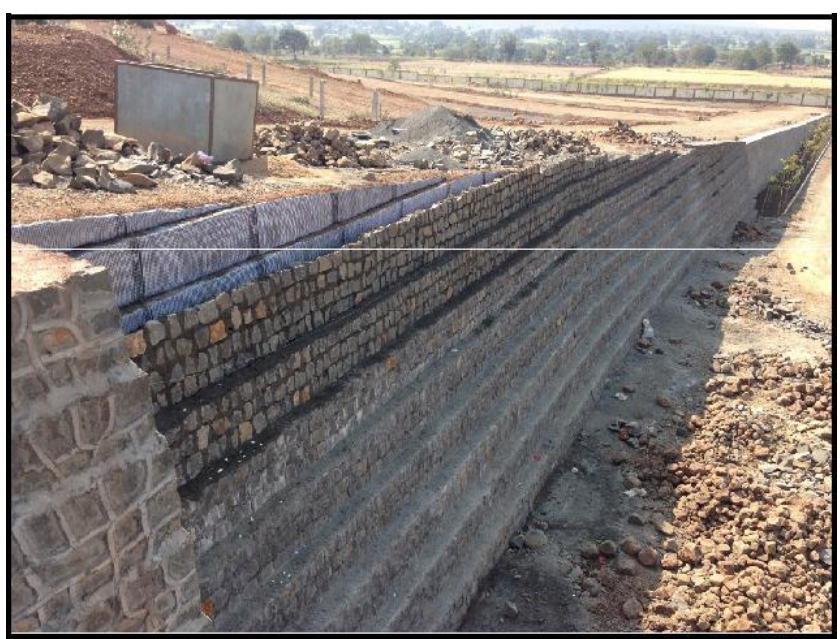

Fig -11: Construction of Wrapped around Reinforced Soil Walls using polyester geogrids

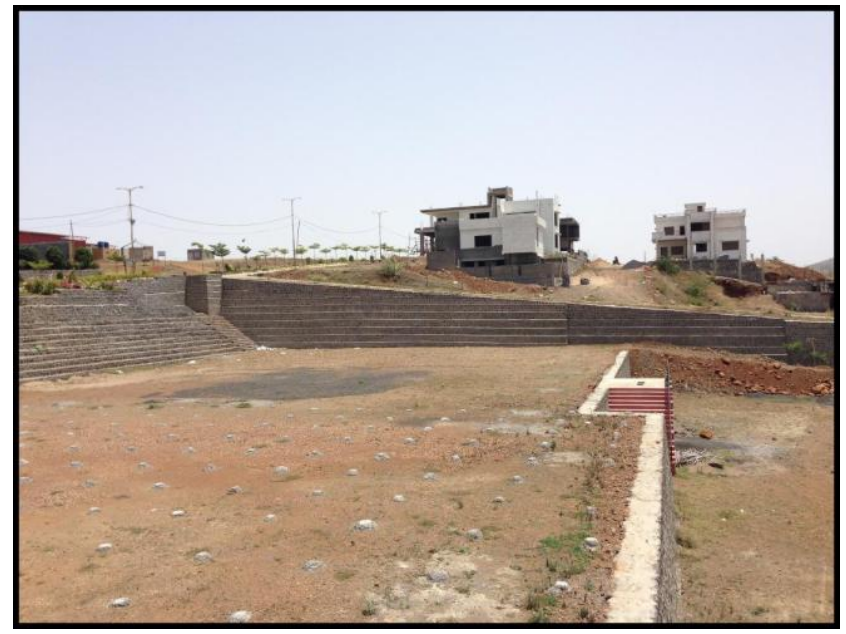

Fig -12: Developed Outdoor Sports Complex using Wrapped around Reinforced Soil Walls

At the face of walls landscaping was also possible; however builder used available materials at site.

The wrapped around reinforced soil walls are economical compare to R.C.C. retaining walls due cost effective components like geogrid and geotextile in place costly materials steel and cements. Installation/construction is also very easy since it is not required shuttering, curing, proper attention to quality of aggregates, mixing etc. Approximately $30 \%$ saving is expected with variety of reinforced soil walls in place of R.C.C. retaining walls. Presently variety reinforced soil walls [1] [2] are well established and well developed technology which is almost forty years old (Availability of International and Indian Codes), must be used confidently in building construction/ housing development projects in place of costly R.C.C. retaining walls to retain earth for any heights.

\subsubsection{Ground Improvement/Stabilization}

Geogrids, Geotextiles and Geocomposites have been used in place of time consuming and costly conventional techniques to improve bearing capacity of foundation soil for highway projects. Builders should also use these Geosynthetics products as a cost effective measures for bearing capacity improvement of weak foundation soil [2] on which building is going to rest as shown in Fig. 13.

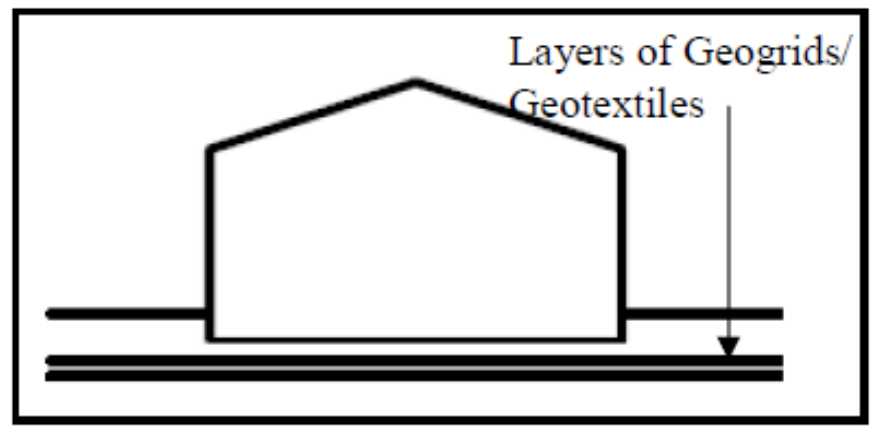

Fig -13: Geogrids and or Geotextile for bearing capacity improvement 
For bearing capacity improvement of the natural soils i.e. wet, soft, compressible and exhibiting very little shear strength; the geogrid and/or geotextile, Geocomposite are placed.

When combination of Geogrid and Geotextile are used then Geotextile (woven and knitted) act as a separator simultaneously allows water from soft natural soil to pass from this soil in to a free draining construction soil, facilitate dissipation of pore pressure and improving mechanical properties of foundation soils (Cohesive/ Non Cohesive), which in turn allows consolidation of the natural soil to take place. As a result of the consolidation process, there is a strength gain in the natural soil. Geogrid is placed at suitable location within foundation soil as a reinforcement to enhance the resistance of embankment to avoid failure through excessive deformation or shear in the foundation soil.

M/s GISPL, Mumbai proposed cost effective ground improvement solution using biaxial geogrid (having tensile strength in both machine and cross machine directions) and geotextile to reinforce foundation soil for $8.0 \mathrm{~m}$ high Reinforced Soil Walls approaches at NH5 as shown in Fig. 14. Reinforced soil walls were going to rest on weak foundation soil as compare to required strength and in the presence of all around water bodies. Foundation soil was having black cotton soil with low bearing capacity up to $5.0 \mathrm{~m}$ depth from ground level and not recommended for construction purposes.

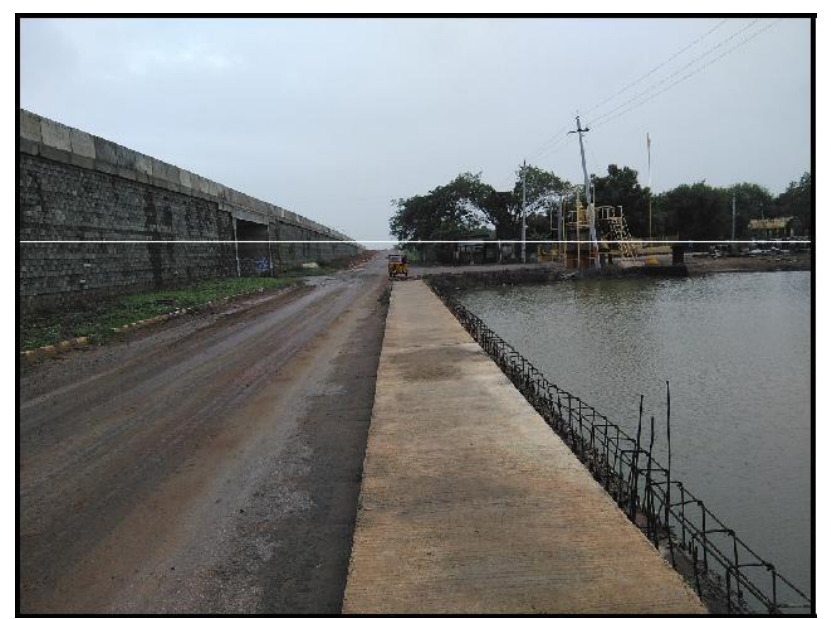

Fig -14: Bearing capacity improvement with Biaxial Geogrids and Geotextile at NH5

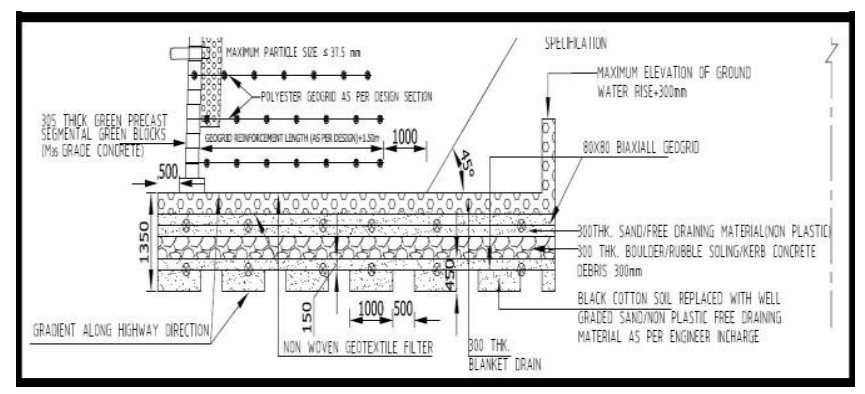

Fig -15: Cross-Section of approach for bearing capacity improvement with Biaxial Geogrids and Geotextile

\subsubsection{Drainage}

Drainage required all structures. In the case of drainage water, flows parallel to the plane of the geotextile as shown in Fig. 16 called transmissivity. The best geotextile for this purpose is staple polyester and polypropylene needlepunched nonwoven geotextile. Some Geocomposite are also well suited to this application. It should be used to remove surface water from a sports field situated within housing complex and sports complex.

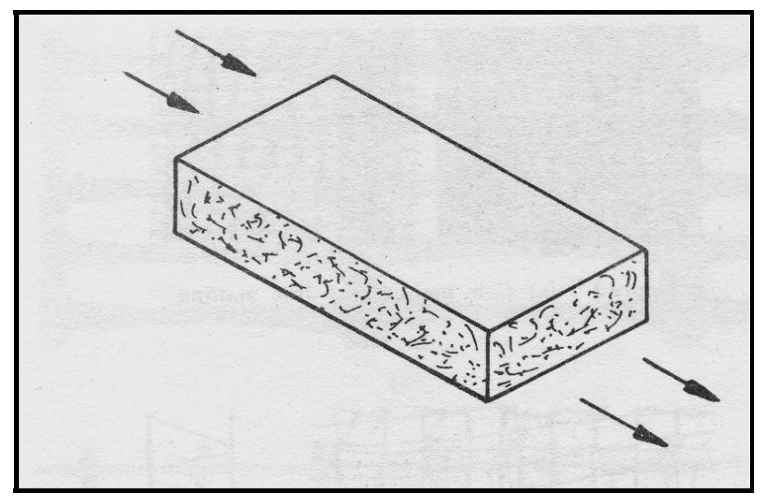

Fig -16: Drainage through Non-Woven Geotextile

\subsubsection{Road Construction}

Geogrids and Geotextiles are already have been extensively used across the world for construction of unpaved and paved roads [3] for its long term performance. Presently, Geosynthetics (Geotextile and Geogrid) is being used within a road pavement system to perform principally two main functions out of 5 functions as mentioned at page number 2 i.e. separation and/or reinforcement as shown in Fig. 17.

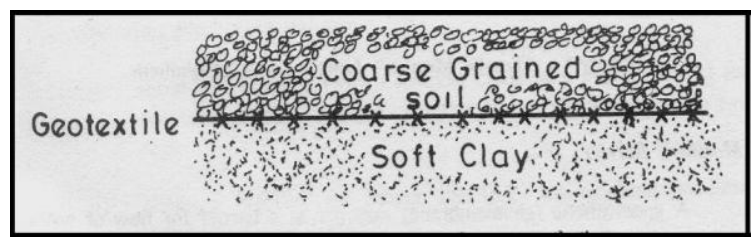

Fig -17: Separation and Reinforcement Function of Geotextile

Geotextiles are used for separation function to avoid intermixing of two different types of materials with each other and maintain pavement thickness as well as control rutting for long period of time.

Geosynthetics like woven Geotextile and biaxial Geogrid are generally used within pavement system for reinforcement function. These Geosynthetics mechanically improves the engineering properties of the pavement system.

The three primary uses of these Geosynthetics in pavement systems are to (a) serve as a construction aid over weak subgrades, (b) improve or increase the pavement's projected service life, and (c) reduce the thickness of design cross section for a given service life. 
In the case of mechanical subgrade stabilization and base reinforcement applications the geotextile is placed as a separation layer on top of the subgrade and geogrid as a reinforcement is then placed directly on top of the geotextile when aggregate layers less than $350 \mathrm{~mm}$. When pavement is having design base thickness (aggregate layer) is greater than or equal to $350 \mathrm{~mm}$, the geogrid shall be placed in the middle of the base course layer [3] [7].

The three fundamental reinforcement mechanisms have been recognized by involving the use of Geosynthetics to reinforce pavement materials: (a) lateral restraint, (b) improved bearing capacity, (c) tensioned membrane effect. Lateral restraint mechanism as shown in Fig. 18, refers to the confinement of the aggregate material during loading/vehicles movement, which restricts lateral spreading of the material from beneath the load. The mechanism of confinement developed due to frictional resistance and/or passive resistance offered by Geosynthetics against lateral movement of aggregate at its interface with base material. Since most aggregates used in pavement systems are stress dependent materials, controlling the lateral movement by confinement action results in an increase in the modulus of the base course material and in turn improved vertical stress distribution applied to the subgrade and a resultant reduction in the vertical strain on the top of the subgrade. The second mechanism, improved bearing capacity as shown in Fig. 19, is achieved by shifting the failure envelops of the pavement system from the relatively weak subgrade to the relatively strong base course material by distributing stresses uniformly over the surface of Geosynthetics. The third reinforcement mechanism as shown in Fig. 20, is tensioned membrane effect. The tensioned membrane effect is based up on the concept of improved vertical stress distribution resulting from tensile stress in a deformed Geosynthetics membrane.

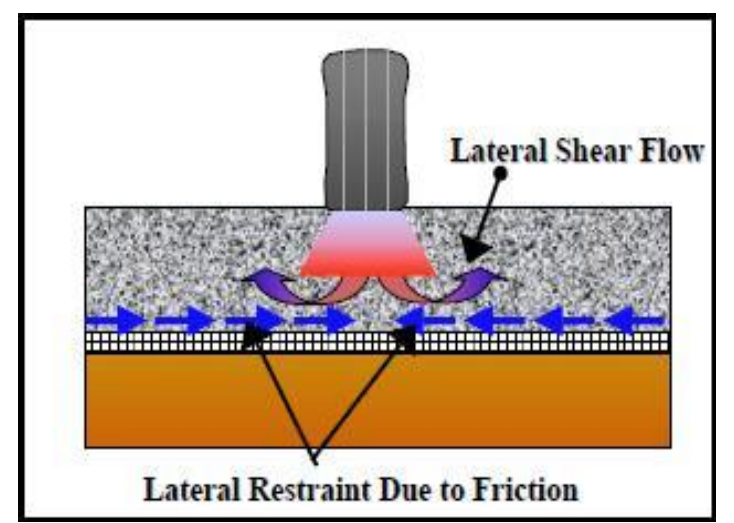

Fig -18: Lateral restraint reinforcement mechanism.

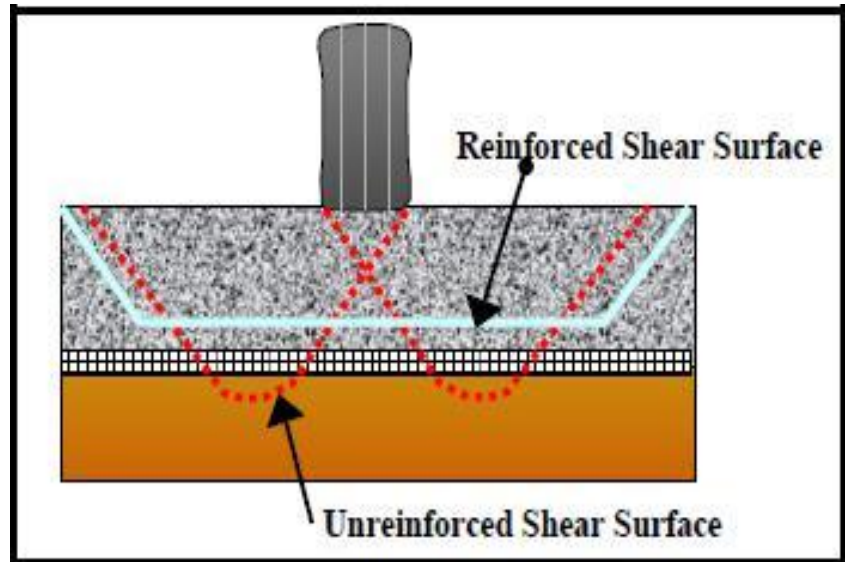

Fig -19: Improved bearing capacity reinforcement mechanism.

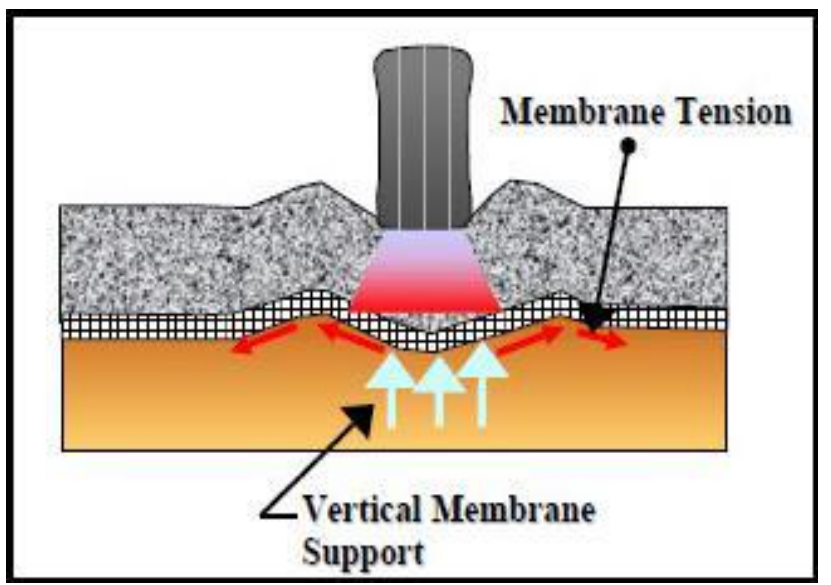

Fig -20: Tensioned membrane effect reinforcement mechanism.

Within any big housing complex Geogrids and Geotextile can be used for construction of internal rods with low maintenance cost or maintenance free roads. Road construction is possible on weak subgrade also due to less deformation by inclusion of geogrids or geotextiles. The diminishing availability of quality aggregates for construction of roads forced engineers to seek design alternatives that reduce the required amount of high quality aggregates. The inclusion of Geosynthetics can reduce the thickness of base material needed. In many cases, this can be cost-effective, as the savings in importing the base material and in repairs to the road can offset the cost of reinforcement.

One field trial [11] was conducted by Prof. B.V.S. Viswanadham from I.I.T. Bombay at MDR 82, in the state of Maharashtra. The design was based on guidelines proposed by Giroud Noiray (1981). Before inclusion of Geosynthetics the rutting depths were observed in a range $200 \mathrm{~mm}$ to $300 \mathrm{~mm}$ and every year new road is constructed. A woven geotextile made of ultra violet treated polypropylene tapes was placed at the interface between the aggregate base course and subgrade. Geotextile functions as a separator to prevent two different materials (subgrade soil and aggregate base course) from intermixing. Geotextile prevent penetration of the base aggregate into subgrade and 
prevent intrusion of subgrade soils into the base course aggregate. Localized bearing failure and subgrade intrusion only occur in very soft, wet, weak sub-grade. Therefore separation due Geosynthetics plays important roles for integrity and functioning of both materials (dissimilar) will remain intact or even be improved. Separation function maintains the designed thickness, stability and load carrying capacity of the base course.

Inclusion of geogrid reinforcement into roadway base gravels allows a reduction in gravel thickness [8], [9] of $30 \%$ to $50 \%$ with no loss in load carrying capacity. The reduction in thickness is accomplished partly by subgrade confinement and partly from improved load distribution characteristics produced by geogrid-base layer material interlocking.

\subsubsection{Erosion Protection Using Natural Geotextile}

Natural geotextiles control slope erosion, happened due to strong winds and rainfall by following mechanism:

a. Providing a protective cover to exposed soil surface,

b. Absorb a large part of kinetic energy of rain drops,

c. Aperture of JGT acts as successive miniature check dams on slopes,

d. Reduces the velocity of run-off

e. Provides overland storage.

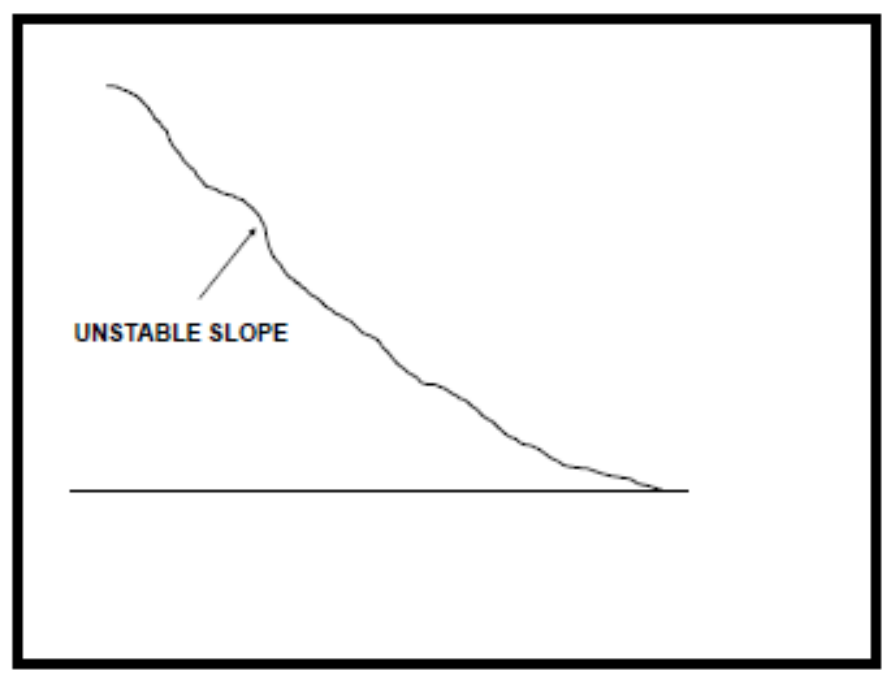

Fig -21: Line Diagram of Steep Unstable Slope.

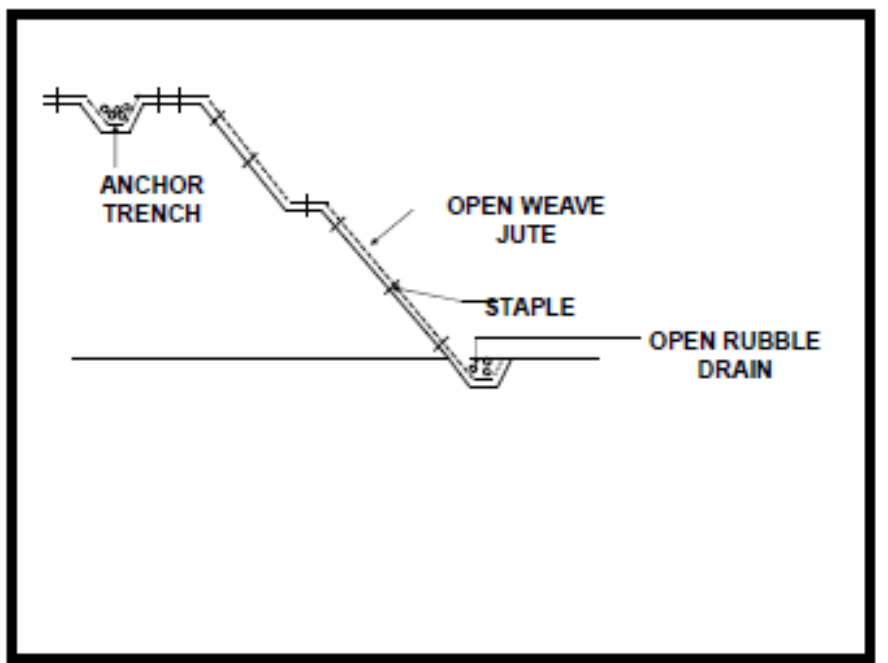

Fig -22: Placing of Natural Geotextile on Steep Unstable Slope.

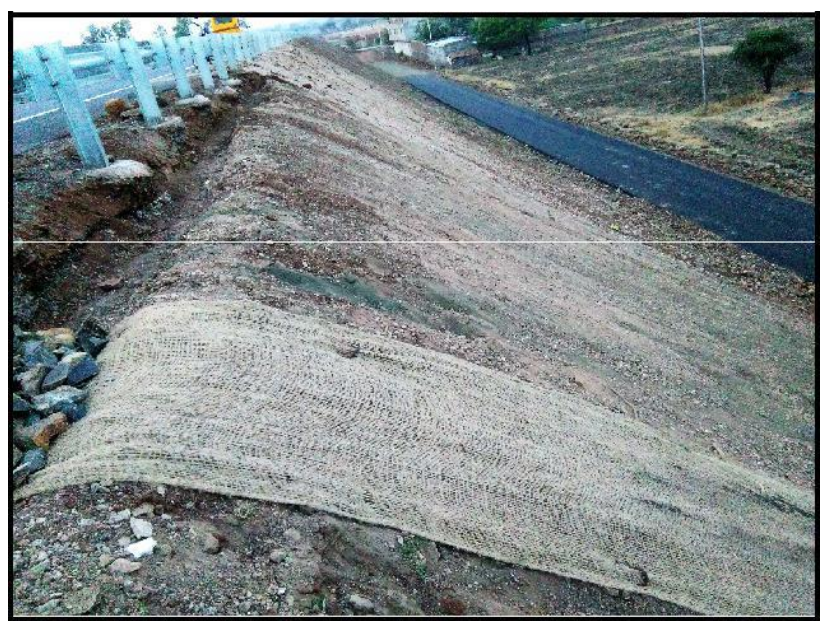

Fig -23: Placing of Natural Geotextile on Steep Slope.

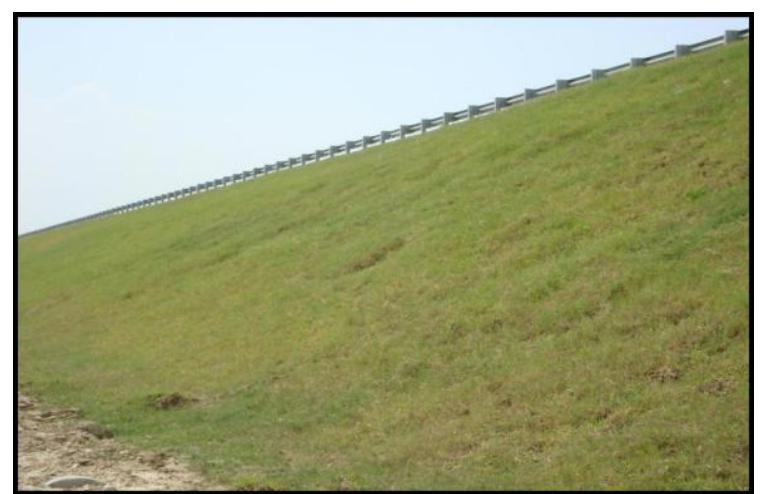

Fig -24: Development of Vegetation on Steep Slope using Natural Geotextile.

\section{GEOMEMBRANES (GM)}

Geomembranes are relatively thin (lowest thickness $0.1 \mathrm{~mm}$ ), two dimensional impervious sheets of polymeric (thermoplastics) or bituminous material with low permeability like PVC/HDPE/LLDPE/ LDPE etc., used primarily for linings, and covers of liquids or solid-storage facilities. Geomembrane provide good resistance against chemicals, environmental stress cracking, puncture, tear and 
simultaneously offer high tensile strength along with low permeability. Applications of Geomembranes include all types of landfills (Bottom seals and capping of communal landfills, side lining), surface impoundments, canals, and other containment facilities like cesspools/tanks used to retain industrial and agriculture waste waters. Thus the primary function is always containment as a liquid or vapor barrier or both and very cost effective, durable than concrete and clay liners.

\subsection{Application of GM as Containment}

The range of applications, however, is wide, and in addition to the environmental area, application are rapidly growing in geotechnical, transportation, hydraulic, and private development engineering (such as aquaculture, agriculture, heap, leach mining etc.).

It involves geomembranes or some geocomposite which function as liquid barriers (as shown in Fig.25)or gas barriers, landfills liners and covers make critical use of these Geosynthetics. All hydraulic applications (tunnel, dams, canals, surface impoundments and floating covers) use these Geosynthetics as well. Geomembrane can use as a temporary storage of water during construction activities. It can be used as water storage tank (as shown in Fig. 26) during monsoon seasons and stored water can be used for various utility purposes. Insulation of reserve tanks foundations, Insulation of petrol station to prevent ground water contamination

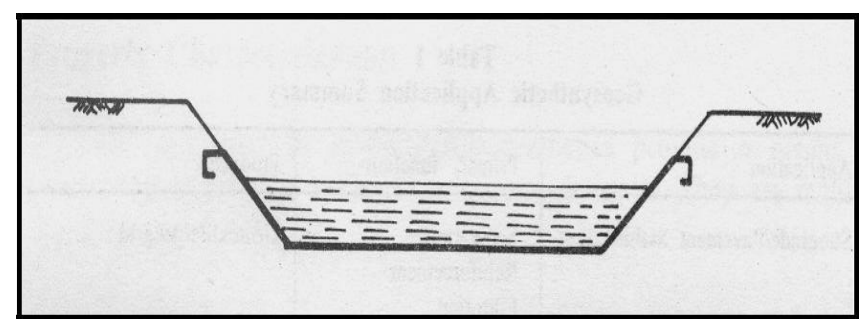

Fig -25: Function of Liquid barrier by Geomembrane

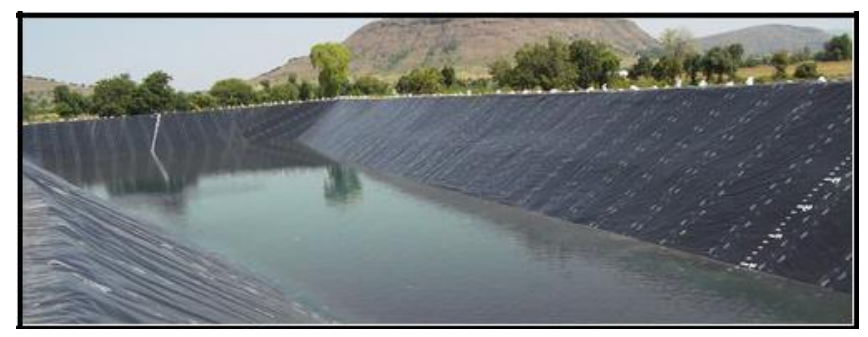

Fig -26: Water Storage during Monsoon Seasons by Geomembrane

\section{GEOCELLS}

The concept of cellular confinement of soils and construction fills to improve their structural performance was pioneered by the U.S. Army Corps of Engineering during late 1970s. The soil-confinement concept was realized commercially with the introduction of product called Geoweb, manufactured by Presto Products Inc. (1985). Geocells [10] (Cellular Confinement System) are three dimensional, honeycombed and open cellular structures that form a confinement system when infilled with compacted soil. These are generally manufactured from polymeric materials like HDPE into strips welded together ultrasonically in series, the strips are expanded to form the stiff (and typically textured and perforated) walls of a flexible 3D cellular mattress. Infilled with soil, a new composite entity is created from the cell-soil interactions. Geocells provide cellular confinement that reduces the lateral spreading of infilled soil particles, thereby maintaining compaction and forms a stiffened mattress that distributes loads over a wider area consequently increasing its load carrying ability. In road construction, when Geocells filled with sand or granular soils, the cellular structure acts like a semi-rigid slab distribution loads laterally, stabilizing base materials, reducing sub grade contact pressures and minimizing surface rutting. Geocells reduces differential settlement even on low-strength subgrades. The geotextile used with Geocells to provide separation between saturated soil and tread fill. Geocells alone does not increase the load bearing capacity of clay or silt. Sandy, rocky soils, crushed aggregate are desirable fill for Geocells. The cell height and diameter varies $75 \mathrm{~mm}$ to $300 \mathrm{~mm}$ and made by the continuous extrusion of HDPE as shown in Fig. 27. Geocells have been used in slope protection and earth retention applications. Geocells made from advanced polymers are being increasingly adopted for long term road and rail road support. Much larger Geocells are made from stiff geotextiles as shown in Fig.28, sewn into similar, but larger, unit cells that are used for protection of bunkers and walls. Advantages with Geocells are:

- Easy to transport,

- Any locally available fill material can be used,

- All round confinement to soil,

- $\quad$ Semi-rigid layer (Very stiff support),

- Distribute loads over a large area,

- Excellent support even under cyclic loads. The applications of Geocells are Erosion control, Steep slopes protection and gravity retaining structures, Subbase reinforcement for Roads, Railway Tracks, and container yards, Structural slab support, Construction of multilayered retaining walls and protective barriers.

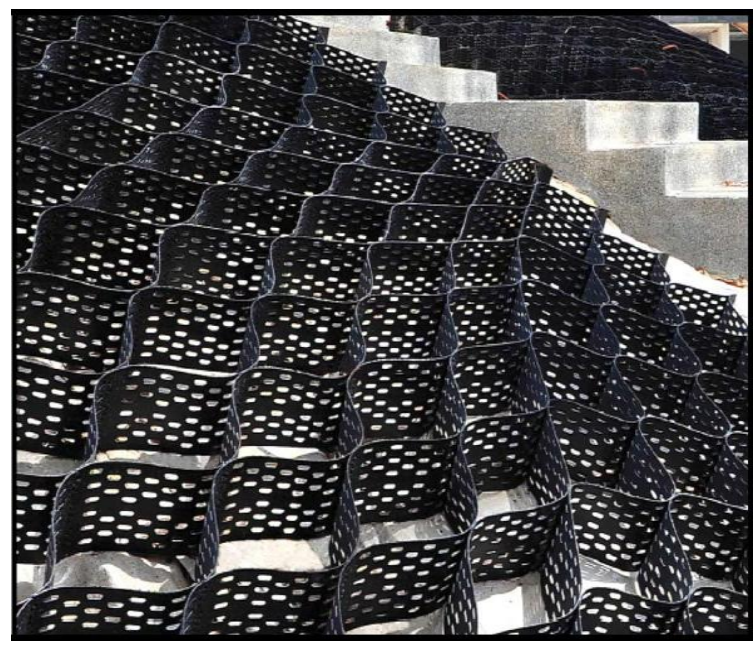

Fig -27: Perforated PE Geocells 


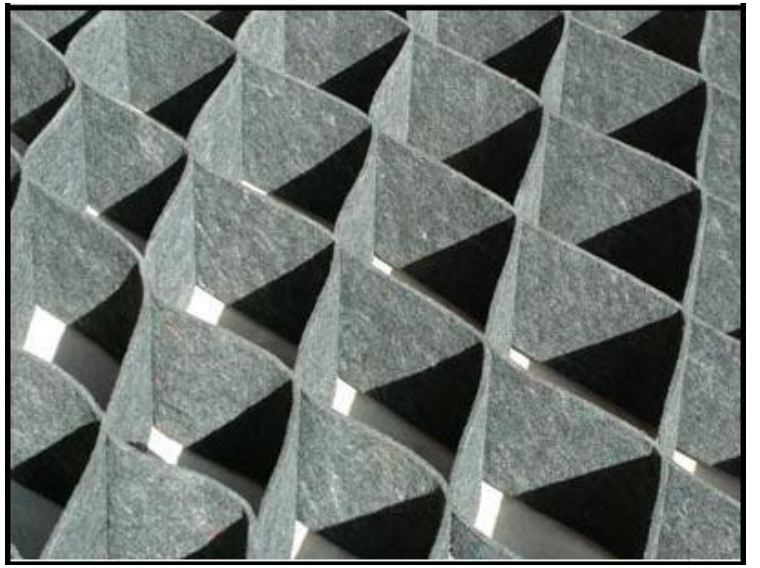

Fig -28: Geocells using stiff Geotextile

\subsection{Geocells Case Studies}

The Presto Products Inc. manufactured first Geocell (non-perforated high density polyethylene (PE) strips welded) in 1985 with the name Geoweb. The Geowebs were used in construction of $3 \mathrm{~m}$ high retaining wall.

The Indian Geosynthetics manufacturer M/s Strata Geosystems (India) Pvt. Ltd., Mumbai have been used HDPE Geocells (StrataWeb ${ }^{\mathrm{TM}}$ ) as an erosion control application and earth retention \& soil stabilization. Geocells were used at Golf course, Gurgaon (Haryana) and at ONGC site in Uran (Maharashtra).

\subsubsection{Case Study 1: Retaining Wall}

The Geocell product "Geoweb" was used to construct $3 \mathrm{~m}$ high retaining wall to support a sloped backfill which in turn was required to mount a $1.8 \mathrm{~m}$ high acoustic barrier between the railway track and the residential properties. A typical cross-section of the gravity retaining wall is shown in Fig. 29.

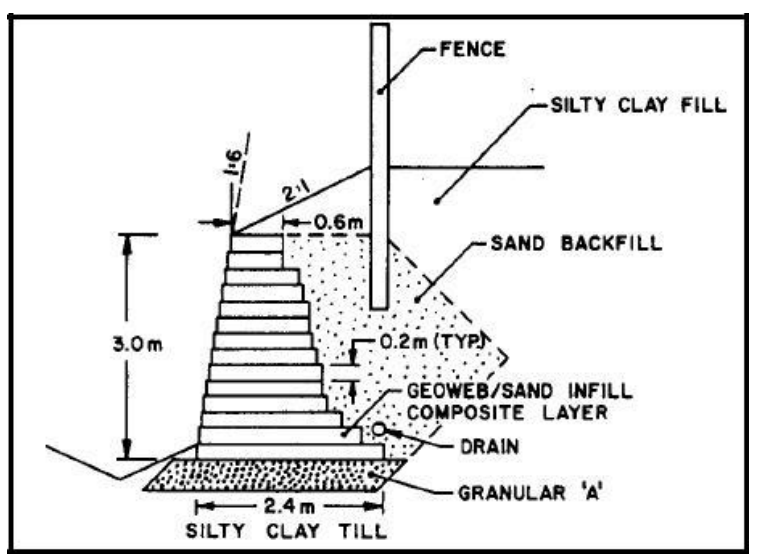

Fig -29: Representative Line Diagram of Gravity Retaining wall using Geoweb.

The Geoweb construction method for this gravity retaining wall was chosen because it offered a relatively quick construction technique on a property with restricted access. The finished structure was also required to be aesthetically pleasing since it is visible from a road leading in to residential properties.
The subsoil at the site comprised approximately $4 \mathrm{~m}$ of silty clay fill overlying natural subsoils. Over approximately onehalf the length of the wall, the subsoils comprised a firm silty clay till and, along the remaining length, a soft compressible organic clay. The structure was founded at the elevation of natural soils. The infill material was sand with maximum particle size $2 \mathrm{~mm}$.

Following excavation of the wall base, a minimum $100 \mathrm{~mm}$ depth of good quality, free draining granular fill (Granular A) was placed and compacted to $95 \%$ of MDD to provide initial working surface. Soft soil were excavated to a depth of $1.0 \mathrm{~m}$ and replaced with (Granular A). The front batter $1(\mathrm{H}): 6(\mathrm{~V})$ was achieved with $35 \mathrm{~mm}$ offset for each subsequent layers from the face of the wall. The construction was easy and very fast. The total 520sqm wall facia completed in 18 working days using backhoe, a tracked loader and 5men despite adverse winter conditions over the duration of the project and restricted site access. During monitoring process wall shows settlement at the base was $50 \mathrm{~mm}$ at the location of soft subsoils and the wall had compressed about $25 \mathrm{~mm}$. These deformations were not visually apparent, and no structural distress of the Geoweb material including the welds was observed. It shows that these structures have ability to tolerate large settlements.

\subsubsection{Case Study 2: Erosion Control}

DLF home developers, Gurgaon has to re-design its 18 holes golf course into a grand 27 holes facility in the heart of Gurgaon in 2014. The redesign is required protection of $30 \mathrm{~m}$ to $40 \mathrm{~m}$ high terrain with slope varies $2(\mathrm{H}): 1(\mathrm{~V})$ to $1: 1$ from erosion. Initially hessian cloth and mulch was tried out but these proved to be inadequate during heavy rainfall. Strata Geo cells worked out to be more economical and sustainable solution than placing of hessian cloth and mulch over steep slopes. Infilling (as shown in Fig.32) with locally available vegetated soil served the landscaping also. During Monitoring erosion was not noticed at site as shown in Fig.33.

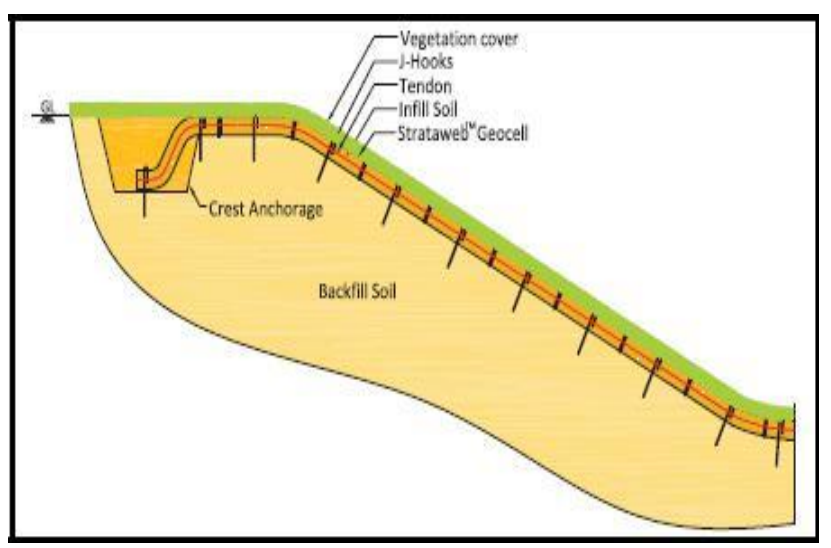

Fig -30: Typical Line Diagram of Erosion control using StrataWeb ${ }^{\mathrm{TM}}$. 


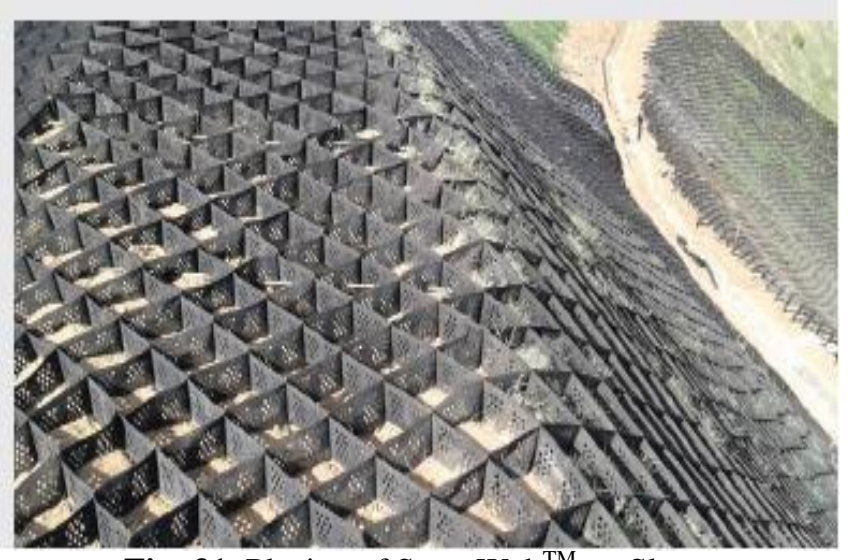

Fig -31: Placing of StrataWeb ${ }^{\mathrm{TM}}$ on Slope

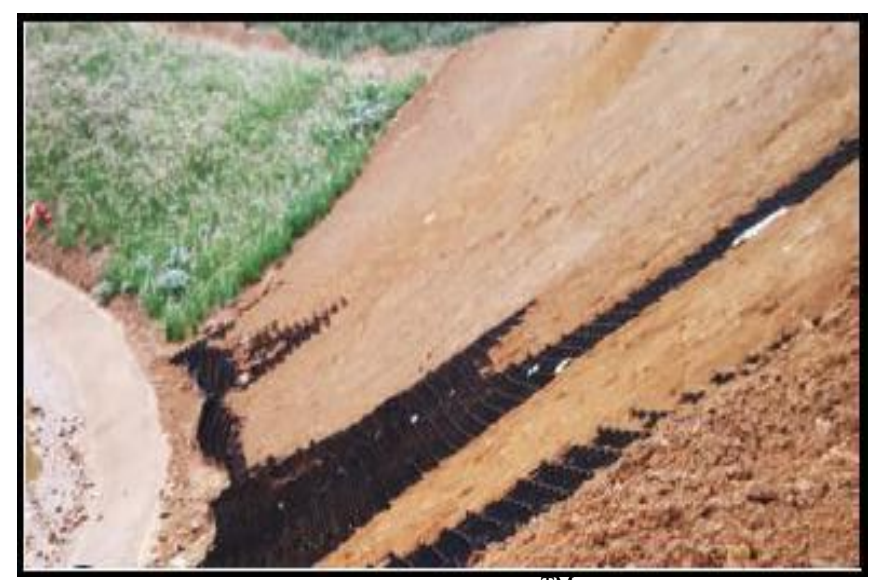

Fig -32: Infilled StrataWeb ${ }^{\mathrm{TM}}$ on Slope

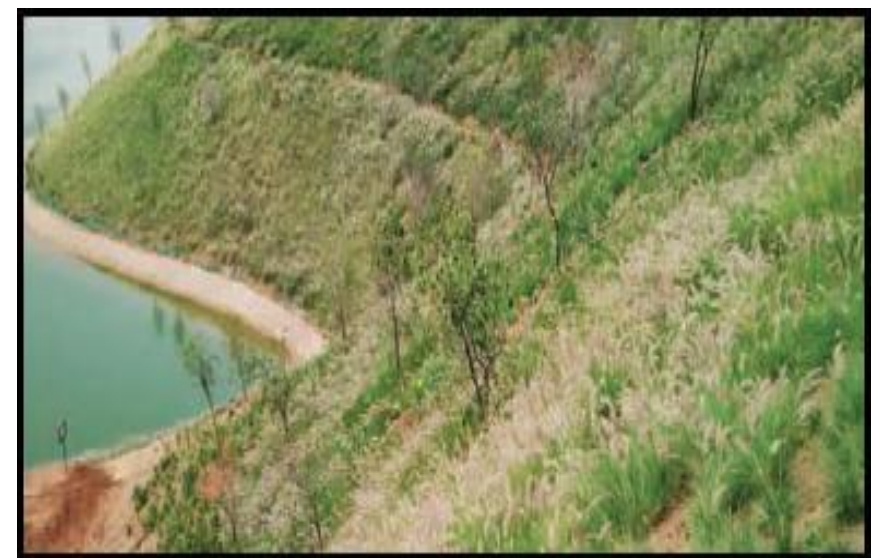

Fig -33: Development of Vegetation through Infilled StrataWeb ${ }^{\mathrm{TM}}$ on Slope

\subsubsection{Case Study 3: Soil Stabilization}

StrataWeb ${ }^{\mathrm{TM}}$ have been used for earth retention and soil stabilization purposes at Aamby Valley, Lonavala, Maharashtra in 2013. Aamby Valley is a hilly terrain and belongs to heavy rainfall zone of Maharashtra. The site was prone to scoring in monsoon seasons. Site shows collapse of soil wedges also due to slope failure at some locations. Slope failure during monsoon season might have been critical if it undermine the plinth and endanger the foundations of the bungalow.

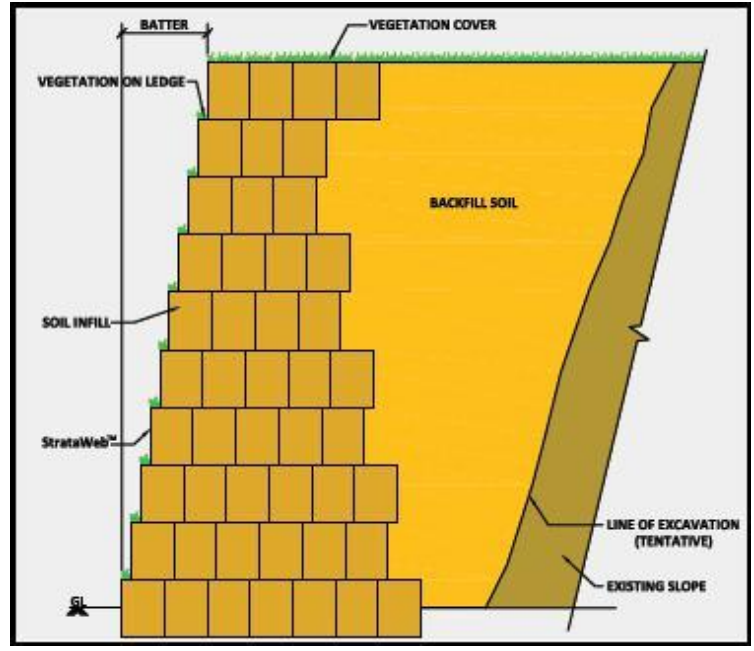

Fig -34: Typical Line Diagram of Gravity Retaining Wall using StrataWeb ${ }^{\mathrm{TM}}$.

A $3 \mathrm{~m}$ high gravity retaining structure was constructed using Strata Geocells (StratWeb) to contain the ground that support foundation of bungalow. The Typical section has shown in Fig. 34. The Gravity retaining wall construction has shown in Fig. 35. The Geocells panels were infilled with locally available lateritic soil and placed one on top of the other. Geocells panels were placed with an inward batter for stability purposes. The batter of each panels also created ledge of soil to form a base to sustain vegetation. Geocells are perforated and this allowed subsurface water that may have seeped in to the slope to flow out without any build-up of pore water pressures. The solution was structurally sound as shown in Fig. 36, maintenance free and can withstand the fury of the monsoons of the Western Ghats of Maharashtra.

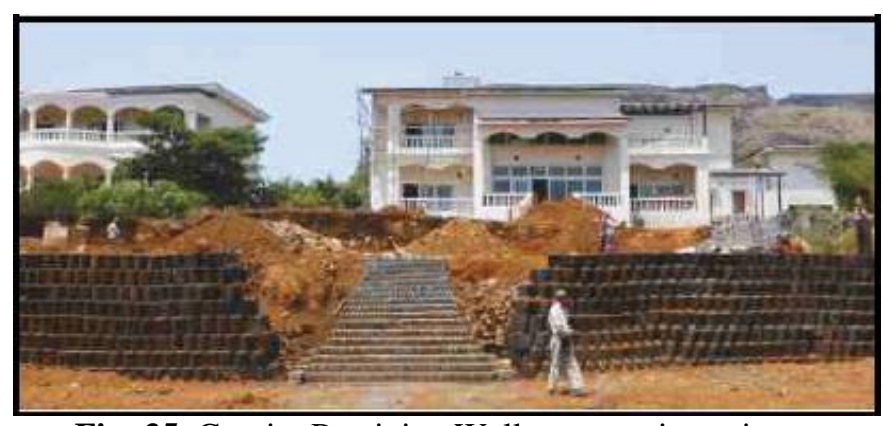

Fig -35: Gravity Retaining Wall construction using StrataWeb ${ }^{\mathrm{TM}}$.

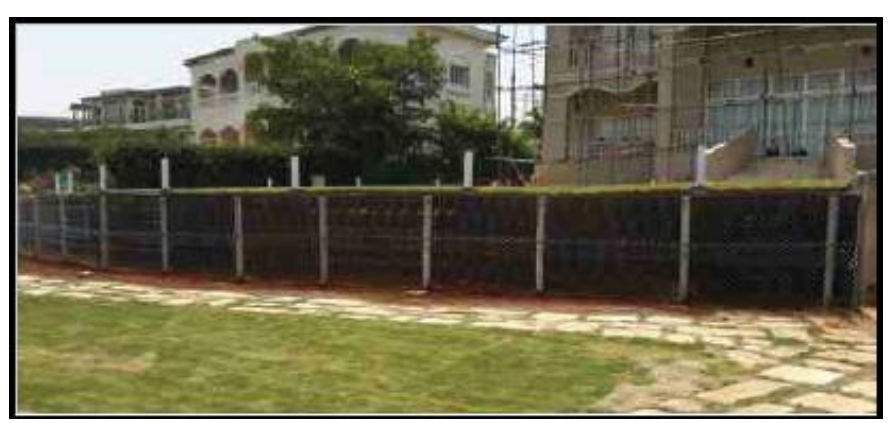

Fig -36: Completion of Gravity Retaining Wall using StrataWeb ${ }^{\mathrm{TM}}$. 


\section{CONCLUSION}

Today, Geosynthetics have found a firm place in Civil Engineering construction across world for both highway and building construction as an alternative of materials of natural conventional materials for similar applications. The advantages with Geosynthetics, it is cost effective and sustainable alternatives of their conventional natural products, not required heavy machinery, easy in installation etc. Presently, various codes, research papers, Government guidelines are available for design and installation procedures of Geosynthetics products for various applications. But In India, use of Geosynthetics products as an alternative of building construction products is negligible or still in the stage of nuisance.

Apart of highway related applications Geosynthetics applications related with building construction industry are: development of maintenance free and cost effective internal roads for townships, stabilization of horse race course by providing a more durable turf track, strengthening of foundation soil to fulfill settlement and bearing capacity criteria for residential complexes, erosion protection of steep slope when foundation is resting in scouring possibility zone, temporary storage of water using geomembrane within township and housing complex, earth retention for development of outdoor sports facility (i.e. tennis court, golf course, badminton court etc.) parking, development of garden etc. within housing complexes/townships, protection of biding foundation etc. Tremendous scope for Geosynthetics products are available and many manufacturers for various types of Geosynthetics for different applications purposes are available in Indian market, but scarcity of knowledgeable \& experience technical personnel is major drawback in selection and promotion of correct Geosynthetics for any Civil Engineering applications. Presently the Geosynthetics Industry is primarily governed by marketing persons who suggest their product based solutions to any problem. Therefore some failure noticed recently, happened due to use of incorrect Geosynthetics and/or designs. Building construction Industry should not completely rely on manufactures suggested solutions until it is verified by independent technical personnel who is not associated with any manufacture in any manner. Selection of correct Geosynthetics products and correct designs procedures is very important point before application of any Geosynthetics at site. In some cases highway related examples have shown in this article due to in the absence of examples related with building construction industry and for development of confidence on Geosynthetics products for similar opportunities, if available in building construction industry.

\section{ACKNOWLEDGEMENT}

- Available Lectures on Geosynthetics by Dr. K. Rajagopal, Professor, Department of Civil Engineering, I.I.T. Madras, Chennai.

- STRATA Geosystems (India) Pvt. Ltd., Mumbai, Maharashtra, India.
- Jute Geotextile, Kolkata, West Bengal, India.

- International Association of Geosynthetic Installers (http://www.iagi.org).

- Geosynthetica.net (www.geosynthetica.net).

\section{REFERENCES}

[1] Elias V., Christopher B. R., and Berg R.R., (2001) FHWA-NHI-00-043."Mechanically Stabilized Earth Walls and Reinforced Soil Slopes Design \& Construction Guidelines".

[2] BS 8006-1: (2010). "Code of practice for strengthened/reinforced soils and other fills".

[3] Department of Transport. "Specification for Road and Bridge Works", $5^{\text {th }}$ Edition, H.M.S.O., London, 1976.

[4] IRC 37 (2001). "Guidelines for the design of flexible Pavements", Indian Road Congress, New Delhi, India.

[5] IS 14986 (2001). "Guidelines for Application of Jute Geotextiles for Rain Water Erosion Control in Road \& Railway Embankment and Hill Slope".

[6] Rajagopal, K., Krishnaswamy, N.R. and Madhavi Latha, G. (1999). "Behavior of Sand Confined with Single and Multiple Geocells", Journal of Geotextiles and Geomembranes, 17, No. 3, 171-184.

[7] Webster, S.L. (1993). "Geogrid Reinforced Base Course for Flexible Pavements for Light Aircraft: Test section Construction, Behavior under Traffic, Laboratory Tests, and Design Criteria, "Technical Report GL-93-6, U.S. Army Engineer Waterways Experiment Station, Vicksburg, MS".

[8] Giroud, J. P. and Noiray, L. (1981). "GeotextileReinforced Unpaved Road Design.", Journal of Geotechnical Engineering, ASCE, Vol. 107, No. 9, pp. 1233-1254.

[9] Giroud, J.P., Ah-line,C. and Bonaparte, R. (1984) "Design of Unpaved Roads and Trafficked Areas with Geogrids", Proc., Symposium on Polymer Grid Reinforcement in Civil Engineering, London, England."

[10] Haas, R. (1986). "Granular Base Reinforcement of Flexible Pavements Using Tensar Geogrids", Tensar Technical Note: BR1.

[11] Viswanadham, B. V. S., Ghosh, B., Gupte A., Satkalmi V. and Bhonsle, S. (2007). "Field Trial on Road Reinforced with Polypropylene Geotextile", National Seminar on Geosynthetics in Engineering Practice, 19-20, Jan 2007, Mumbai.

\section{BIOGRAPHIES}

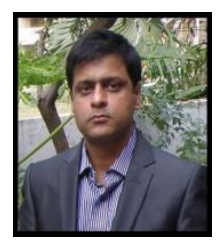

Aanand Jain, CEO of M/s Green Infrastructures Systems Pvt. Ltd. Mumbai, working on Geosynthetics since 2005. During post-graduation from I.I.T. Bomaby, Mumbai, his technical paper was published in $20^{\text {th }}$ International Confrence, Philadelphia, PA, USA, 3-6 April 